\title{
Kemampuan Pemecahan Masalah Matematis Siswa dalam Menyelesaikan Soal PISA pada Topik Geometri
}

\author{
Anas Ma'ruf Annizar', Mohammad Archi Maulyda ${ }^{2 *}$, Gusti Firda Khairunnisa ${ }^{3}$, Lailin \\ Hijriani $^{4}$ \\ ${ }^{1}$ Program Studi Tadris Matematika, Institut Agama Islam Negeri Jember \\ ${ }^{2}$ Program Studi Pendidikan Guru Sekolah Dasar, Universitas Mataram \\ ${ }^{3}$ Program Studi Pendidikan Matematika, Universitas Islam Malang \\ ${ }^{4}$ Program Studi Pendidikan Matematika, Universitas Timor \\ *archimaulyda@unram.ac.id
}

\begin{abstract}
Abstrak
Penelitian ini bertujuan untuk mendeskripsikan kemampuan pemecahan masalah matematis siswa dalam menyelesaikan masalah dari Programme for International Student Assessment (PISA) terkait topik geometri. Subjek penelitian dipilih dengan memperhatikan hasil tes awal kemampuan matematika dari 53 siswa kelas X. Kemudian siswa dikelompokkan dalam kategori kemampuan matematika tinggi, sedang, dan rendah. Dari setiap kategori dipilih satu siswa sebagai subjek penelitian dengan memperhatikan kemampuan komunikasinya agar memudahkan peneliti mengetahui detail proses siswa dalam menyelesaikan masalah. Penelitian dilakukan dengan memberi subjek suatu masalah dari PISA terkait topik geometri, dan dilanjutkan dengan mewawancarai setiap subjek. Hasil pekerjaan subjek dan wawancara kemudian dianalisis menggunakan metode deskriptif kualitatif. Hasil penelitian menunjukkan bahwa subjek berkemampuan matematika tinggi mampu memahami masalah, merencanakan, dan melaksanakan strategi dengan baik, serta melakukan pengoreksian kembali pada bagian perhitungannya. Subjek berkemampuan matematika sedang membuat kesalahan dalam memahami masalah dan dalam perencanaan, sehingga subjek melaksanakan strategi yang salah, selain itu subjek melakukan pengoreksian pada konsepnya saja. Subjek berkemampuan rendah membuat kesalahan dalam memahami masalah dan dalam merencanakan strategi pemecahan masalah, sehingga subjek menerapkan strategi yang salah. Selain itu subjek berkemampuan matematika rendah tidak melakukan pengoreksian kembali.
\end{abstract}

Kata kunci: geometri, kemampuan pemecahan masalah, PISA

\begin{abstract}
This study aims to describe the mathematical problem solving ability of students in solving geometry problem of Programme for International Student Assessment (PISA). Subjects were selected by considering the result of mathematics abilitiy of 53 students in grade $\mathrm{X}$ through a preliminary problem. Then, the students was grouped into 3 categories: high-skilled subject, medium-skilled subject, and low-skilled subject. From each categories, researcher picked one student as a research subject considering their communication skill to make researcher easy to describe subects' process in solving problem. Research was held by give each subject a geometry problem which is adapted from PISA problem, and then researcher give an interview to each subject. The results of this study analyzed by descriptive qualitative method. The results showed that the high-skilled subject abled in understanding the problem, planning, and implementing strategy properly, as well as looking back in the calculation section. For the medium-skilled subject already made mistakes in understanding and planning the problem, so that the subject implemented the wrong strategy, in addition the subject corrected to the concept only. The low-skilled subject
\end{abstract}


made mistakes in understanding and planing the problem so that the subject implemented the wrong strategy. In addition, the low-skilled subject did not look back at his work.

Keywords: geometry, problem solving skill, PISA

Received: November 28, 2019 / Accepted: January 5, 2020 / Published Online: January 31, 2020

\section{Pendahuluan}

Programme for International Student Assesment (PISA) merupakan suatu program yang diinisiasi oleh Organization for Economic Co-operation and Development (OECD) yang bertujuan untuk mengevaluasi sistem pendidikan secara global. PISA memberikan asesmen yang berfokus pada kemampuan membaca, matematika, sains, dan pemecahan masalah kepada anak-anak berusia 15 tahun setiap tiga tahun. Indonesia mengikuti PISA pertama kali pada tahun 2001. Namun, prestasi Indonesia pada PISA 2018 masih berada di urutan ke 72 dari 77 negara, dengan skor kemampuan matematis siswa sebesar 379. Skor ini di bawah skor rata-rata, yaitu 489 (OECD, 2019). Fakta ini menunjukkan bahwa kemampuan matematika siswa-siswa di Indonesia masih tergolong rendah dibandingkan negara-negara lain.

Salah satu indikator dari masalah-masalah PISA adalah pemecahan masalah. Pemecahan masalah dapat dipandang sebagai usaha mencari jalan keluar dari suatu kesulitan, mencapai suatu tujuan yang tidak begitu saja dengan segera dapat diperoleh (Polya, 2004). Murdiyani, dkk. (2013) menyatakan bahwa pemecahan masalah adalah suatu pemikiran yang terarah secara langsung untuk menemukan suatu solusi atau jalan keluar untuk masalah yang spesifik. Dari definisi tersebut dapat disimpulkan bahwa pemecahan masalah merupakan suatu proses usaha seseorang dengan menggunakan segala pengetahuan, keterampilan, dan pemahaman yang dimilikinya untuk menemukan solusi atas permasalahan yang diberikan atau dihadapinya. Pentingnya pemecahan masalah ditegaskan oleh The National Council of Teachers of Mathematics (2000) bahwa ada beberapa alasan mengapa pemecahan masalah sangat penting dalam pembelajaran saat ini yaitu: (1) pemecahan masalah merupakan bagian dari matematika; (2) matematika memiliki aplikasi dan penerapan; (3) adanya motivasi intrinsik yang melekat dalam persoalan matematika; (4) persoalan pemecahan masalah bisa menyenangkan; dan (5) mengajarkan siswa untuk mengembangkan teknik memecahkan masalah.

Prestasi Indonesia pada PISA, khususnya kemampuan matematis yang masih berada di bawah rata-rata negara-negara yang berpartisipasi dalam PISA, menunjukkan bahwa siswa di Indonesia masih memiliki keterampilan yang kurang dalam pemecahan masalah. Oleh sebab 
itu, kemampuan pemecahan masalah siswa di Indonesia perlu ditingkatkan. Salah satunya adalah dengan cara memberikan latihan pemecahan masalah dari persoalan yang tidak rutin (Lestari \& Sofyan, 2014; Nalurita, dkk., 2019). Di samping memberikan permasalahan yang tidak rutin, guru juga harus dapat memantau perkembangan kemampuan pemecahan masalah siswa untuk mengetahui tingkat kemampuan pemecahan masalahnya dan bagian manakah yang perlu untuk ditingkatkan. Lebih jauh Croft, dkk. (2018) mengemukakan bahwa pemecahan masalah dapat berperan sebagai sarana untuk mengembangkan pemikiran matematika sebagai alat untuk hidup sehari-hari. Dari penjelasan tersebut maka kemampuan pemecahan masalah yang baik sangat penting untuk dimiliki siswa.

Salah satu konten matematika yang diujikan pada PISA adalah mengenai ruang dan bentuk. Topik ini berkaitan dengan geometri dan sebenarnya merupakan salah satu topik matematika yang sangat dekat dengan kehidupan siswa, namun siswa mengalami kesulitan dalam menyelesaikan masalah terkait topik geometri. Siswa memiliki keterampilan prosedural yang cukup untuk menyelesaikan masalah yang rutin, namun kesulitan untuk mengaplikasikan pengetahuan yang dimiliki untuk menyelesaikan masalah yang tidak rutin (Novita, dkk., 2018; Sholihah \& Afriansyah, 2017).

Berdasarkan paparan di atas maka perlu dilakukan suatu penelitian untuk mengetahui cara dan kemampuan siswa dalam memecahkan masalah geometri, khususnya pada masalahmasalah geometri yang diujikan oleh PISA, karena berdasarkan data dari OECD (2019), siswa di Indonesia tampak memiliki prestasi yang kurang dalam memecahkan masalah-masalah PISA. Beberapa penelitian telah mengangakat topik kesulitan siswa dalam menyelesaikan soal-soal PISA, seperti penelitian yang dilakukan oleh Haji, dkk. (2018), Dimas, dkk. (2018), dan Ambarwati, dkk. (2018). Namun belum ditemukan penelitian yang mengangkat topik kesulitan siswa dalam menyelesaikan soal-soal PISA dengan konten geometri. Padahal penting untuk mengetahui kemampuan serta letak kesulitan siswa dalam pemecahan masalah geometri, dengan demikian pendidik dapat mengontrol dan mengetahui aspek apa yang perlu ditingkatkan dalam mengembangkan kemampuan permecahan masalah siswa. Untuk mengevaluasi kemampuan pemecahan masalah siswa diperlukan suatu indikator, dalam artikel ini indikator kemampuan masalah diadaptasi dari tahap-tahap pemecahan masalah yang digagas oleh Polya (2004), yaitu memahami masalah, merencanakan strategi pemecahan masalah, melaksanakan strategi, dan mengoreksi kembali. 


\section{Metode}

Jenis penelitian yang digunakan adalah kualitatif dengan pendekatan deskriptf. Pendekatan deskriptif dipilih karena peneliti ingin mendeskripsikan proses pemecahan masalah yang dilakukan siswa ketika diberikan masalah PISA pada topik Geometri (Creswell, 2012). Penelitian dilakukan di Lembaga Bimbingan Belajar (LBB) di kota Jember yang karakteristik siswanya heterogen jika ditinjau dari kemampuan matematikanya dan saat penelitian berlangsung berusia 15 tahun. Pemilihan subjek penelitian dilakukan dengan cara pemberian soal awal untuk menjaring siswa LBB yang akan dijadikan subjek penelitian. Soal awal ini diberikan kepada 53 siswa LBB. Instrumen soal yang diberikan merupakan kategori soal non rutin atau masalah non rutin. Tujuan dilakukannya pemberian soal tes awal ini yaitu untuk menjaring siswa-siswa yang memiliki kemampuan pemecahan masalah. Hasil pekerjaan siswa akan dianalisis dengan mengamati proses penyelesaian masalah yang diberikan.

Berdasarkan hasil tersebut, peneliti mengkategorikan hasil pekerjaan siswa dalam 3 kategori yakni siswa dalam kategori tinggi, sedang dan rendah. Adapun pengkategoriannya menggunakan tabel di bawah ini.

Tabel 1. Pengkategorian kemampuan siswa berdasarkan skor

\begin{tabular}{lc}
\hline \multicolumn{1}{c}{ Kategori } & Skor Interval \\
\hline Subjek Berkemampuan Tinggi & $80 \leq$ Skor \\
Subjek Berkempuan Sedang & $60 \leq$ Skor $<80$ \\
Subjek Berkemampuan Rendah & Skor $<60$ \\
\hline
\end{tabular}

Siswa yang berada dalam kategori kemampuan matematika tinggi merupakan siswa yang dapat menyelesaikan masalah dengan baik. Siswa yang berada dalam kategori kemampuan matematika sedang adalah siswa yang dapat membuat strategi penyelesaian masalah yang baik namun hasil akhirnya masih tidak tepat. Sedangkan siswa yang berada dalam kategori kemampuan matematika rendah adalah siswa yang tidak dapat memahami masalah dengan baik, yang mengakibatkan strategi penyelesaian dan hasil akhirnya tidak tepat. Setelah itu dipilih 3 subjek penelitian yang memenuhi kriteria sebagai berikut: (1) mewakili kemampuan matematika tinggi, sedang, dan rendah; (2) memiliki kemampuan komunikasi yang baik sehingga mudah menjelaskan hasil pekerjaanya; (3) hasil diskusi dengan tutor LBB.

Setelah itu ketiga subjek penelitian yang terpilih diberikan soal tes uraian masalah untuk melihat bagaimana proses pemecahan masalah subjek penelitian. Setelah subjek penelitian menyelesaikan soal tesnya, subjek penelitian akan diwawancara untuk mengonfirmasi hasil penyelesaian masalah dari subjek. Adapun indikator pemecahan masalah yang digunakan 
untuk menganalisis hasil pekerjaan subjek merupakan hasil adaptasi dari indikator kemampuan pemecahan masalah yang dirumuskan oleh Polya (2004) sebagai berikut:

Tabel 2. Indikator kemampuan pemecahan masalah

\begin{tabular}{lll}
\hline \multicolumn{1}{c}{ Indikator } & & \multicolumn{1}{c}{ Deskripsi } \\
\hline Memahami Masalah & - & Subjek mengetahui informasi yang ada pada soal \\
Merencanakan & - Subjek mengetahui apa yang ditanyakan pada soal \\
Strategi & - Subjek mampu mencari informasi lain yang berguna \\
& & dalam menyelesaikan permasalahan dengan \\
& - & Subjek mampu menyusun strategi untuk penyelesaian \\
& & permasalahan \\
Melaksanakan & - Subjek mampu untuk melaksanakan strategi yang telah \\
Strategi & dibuat \\
Mengoreksi Kembali & - Subjek melakukan pengkoreksian kembali pada bagian \\
& konsep \\
& - Subjek melakukan pengkoreksian kembali pada bagian \\
& perhitungan (kalkulasi) \\
\hline
\end{tabular}

Instrumen tes yang digunakan dalam penelitian ini diambil dari soal PISA yang membutuhkan kemampuan pemecahan masalah untuk dapat mencari solusi dari masalah yag diberikan. Berikut adalah soal yang digunakan dalam penelitian ini.

Pak Budi memilih model garasi seperti pada gambar di bawah ini. Posisi jendela dan pintu ditunjukkan seperti pada gambar.

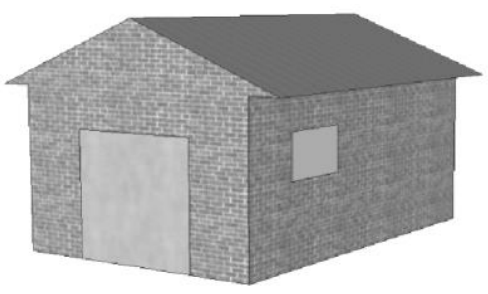

Dua gambar di bawah menunjukkan dimensi dari garasi yang dipilih Pak Budi dalam satuan meter.
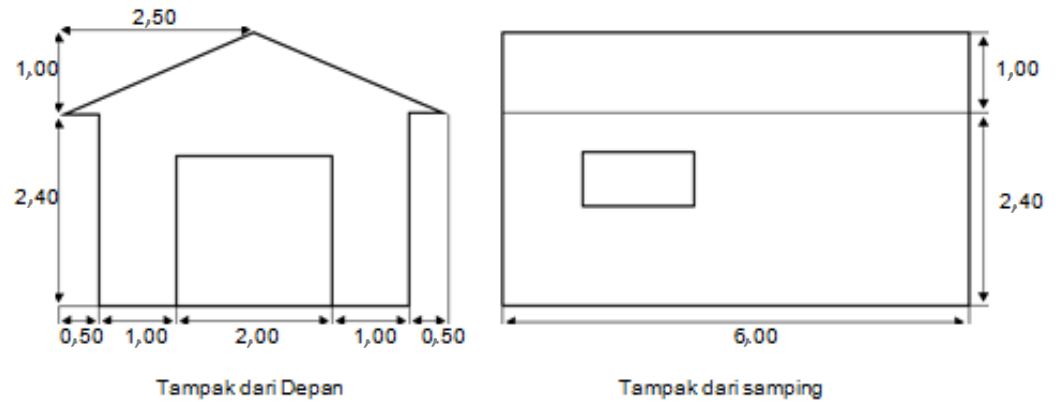

Atap garasi dibuat dari 2 persegi panjang yang kongruen. Hitunglah luas total atap garasi

Pak Budi. Tuliskan langkah-langkah untuk menemukan jawabanmu! 


\section{Hasil Penelitian}

Tes awal diberikan kepada subjek penelitian untuk mengklasifikasikan tingkat kemampuan matematika masing-masing subjek. Instrumen tes yang diberikan dibuat oleh peneliti berkolaborasi dengan tutor di bimbel tersebut sesuai dengan materi yang sedang dipelajari oleh subjek penelitian. Instrumen tes berisikan 3 butir soal yang diberikan kepada siswa, kemudian dari ketiga soal yang diberikan, peneliti memberikan skor keseluruhan dan pengkategorian subjek penelitian menjadi subjek berkemampuan matematika tinggi, sedang, dan rendah dilakukan dengan mempertimbangkan skor total yang didapatkan subjek saat mengerjakan ke tiga soal tersebut.

Berdasarkan hasil pekerjaan 53 siswa pada lokasi penelitian yang telah ditetapkan yakni lembaga bimbingan belajar, didapatkan data sebagai berikut.

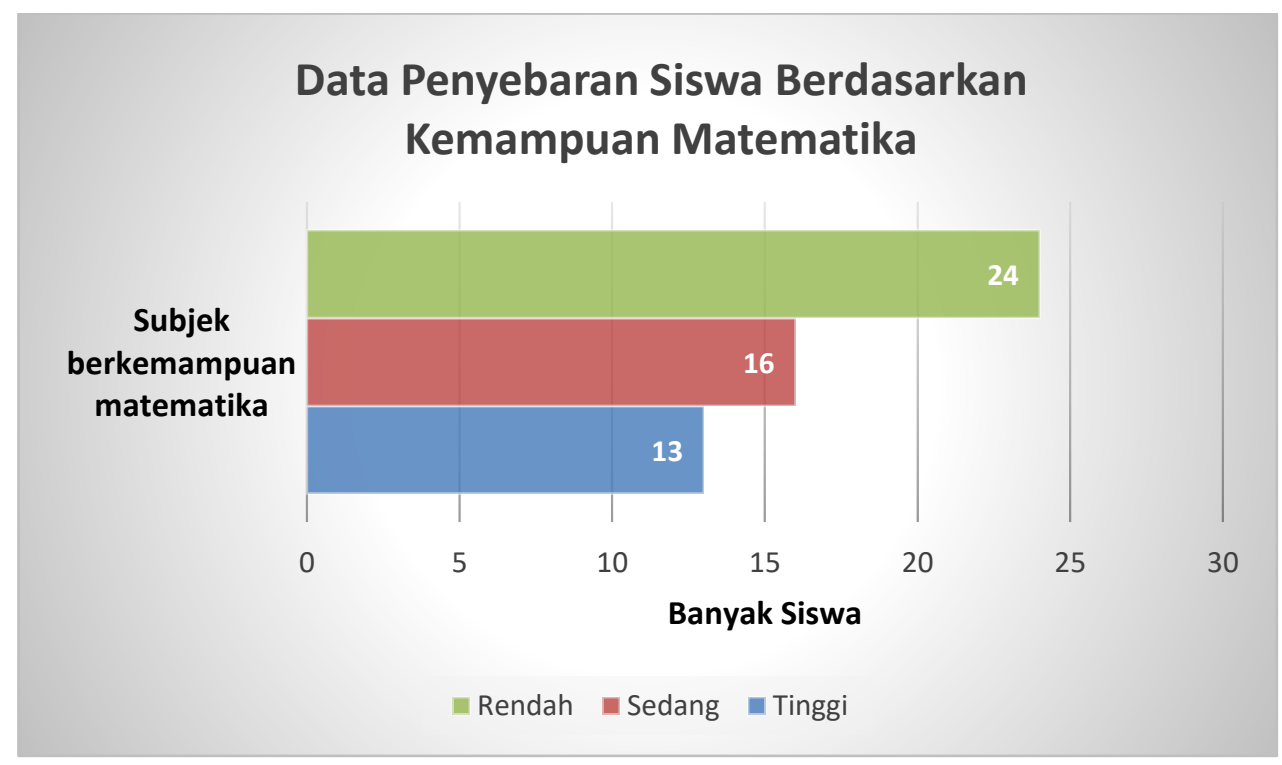

Gambar 1. Kategorisasi Kemampuan Matematika Siswa

Data tersebut menunjukkan bahwa dari 53 pekerjaan siswa, peneliti mengklasifikasikannya menjadi 24 orang berkategori matematika rendah, 16 orang berkategori matematika sedang dan 13 orang berkategori matematika tinggi. Berdasarkan diskusi dengan tentor yang mengajar di kelas tersebut, direkomendasikan subjek pertama (S1), subjek kedua (S2), dan subjek ketiga (S3) yang memiliki komunikasi cukup baik untuk mewakili berturut-turut kategori matematika tinggi, sedang dan rendah. Selanjutnya dari ketiga subjek tersebut diberikan soat tes pemecahan masalah yang sudah disiapkan lalu dilanjutkan dengan melakukan sesi wawancara. Tabel 3 berikut ini merupakan hasil pemecahan masalah S1, S2, dan S3. 
Tabel 3. Ringkasan proses pemecahan masalah

\begin{tabular}{|c|c|c|c|}
\hline Pemecahan Masalah & S1 & $\mathbf{S 2}$ & S3 \\
\hline Memahami Masalah & $\begin{array}{l}\text { Subjek tidak } \\
\text { menuliskan apa yang } \\
\text { diketahui dan } \\
\text { ditanyakan } \\
\text { menggunakan } \\
\text { symbol yang jelas, } \\
\text { namun berdasarkan } \\
\text { pekerjaannya terlihat } \\
\text { bahwa subjek } \\
\text { sebenarnya } \\
\text { memahami } \\
\text { penggunaan simbol- } \\
\text { simbol meskipun } \\
\text { tidak dituliskannya }\end{array}$ & $\begin{array}{l}\text { Subjek menuliskan } \\
\text { apa yang diketahui } \\
\text { dan ditanya seperti } \\
\text { panjang, lebar, dan } \\
\text { luas menggunakan } \\
\text { simbol panjang dan } \\
\text { lebar dengan benar, }\end{array}$ & $\begin{array}{l}\text { Subjek menuliskan } \\
\text { apa yang diketahui } \\
\text { masih belum benar } \\
\text { meskipun telah dapat } \\
\text { menuliskan simbol } \\
\text { panjang dan lebar } \\
\text { dengan tepat }\end{array}$ \\
\hline $\begin{array}{l}\text { Merencanakan } \\
\text { Strategi }\end{array}$ & $\begin{array}{l}\text { Subjek mampu } \\
\text { untuk merencanakan } \\
\text { strategi bahkan } \\
\text { mencari variabel lain } \\
\text { yang menunjang } \\
\text { dalam pencapaian } \\
\text { solusi menggunakan } \\
\text { strategi yang } \\
\text { dimiliki }\end{array}$ & $\begin{array}{l}\text { Kemampuan } \\
\text { merencanakan } \\
\text { strategi subjek ini } \\
\text { masih belum cukup } \\
\text { baik, yang } \\
\text { disebabkan karena } \\
\text { kesalahan dalam } \\
\text { memahami masalah } \\
\text { sehingga tidak } \\
\text { mampu mengaitkan } \\
\text { informasi yang ada } \\
\text { untuk mencari } \\
\text { informasi yang } \\
\text { belum diketahui }\end{array}$ & $\begin{array}{l}\text { Subjek berkategori } \\
\text { rendah dikatakan } \\
\text { belum mampu } \\
\text { menyusun strategi } \\
\text { dengan tepat karena } \\
\text { terjadi kegagalan } \\
\text { dalam mengaitkan } \\
\text { informasi yang ada }\end{array}$ \\
\hline $\begin{array}{l}\text { Melaksanakan } \\
\text { Strategi }\end{array}$ & $\begin{array}{l}\text { Subjek } \\
\text { melaksanakan } \\
\text { strategi dengan baik } \\
\text { meskipun lupa untuk } \\
\text { tidak menuliskan } \\
\text { satuan lebar }\end{array}$ & $\begin{array}{l}\text { Rencana yang dibuat } \\
\text { kurang sesuai } \\
\text { dengan } \\
\text { permasalahan, dan } \\
\text { mengakibatkan } \\
\text { strategi yang } \\
\text { dilaksanakan kurang } \\
\text { sesuai }\end{array}$ & $\begin{array}{l}\text { Karena rencana yang } \\
\text { dibuat kurang sesuai } \\
\text { dengan } \\
\text { permasalahan } \\
\text { sehingga } \\
\text { mengakibatkan } \\
\text { strategi yang } \\
\text { dilaksanakan kurang } \\
\text { tepat }\end{array}$ \\
\hline $\begin{array}{l}\text { Mengkoreksi } \\
\text { kembali }\end{array}$ & $\begin{array}{l}\text { Subjek melakukan } \\
\text { pengoreksian } \\
\text { kembali pada bagian } \\
\text { perhitungannya saja, } \\
\text { dan tidak melakukan } \\
\text { pengoreksian pada } \\
\text { bagian rumus dan } \\
\text { konsep }\end{array}$ & $\begin{array}{l}\text { Subjek melakukan } \\
\text { pengkoreksian hanya } \\
\text { pada konsepnya saja } \\
\text { yakni pada bagian } \\
\text { menentukan lebar } \\
\text { atap yang dimaksud } \\
\text { pada soal }\end{array}$ & $\begin{array}{l}\text { Subjek tidak } \\
\text { melakukan } \\
\text { pengoreksian } \\
\text { kembali baik dalam } \\
\text { perhitungan, rumus } \\
\text { maupun konsepnya. }\end{array}$ \\
\hline
\end{tabular}




\section{Pembahasan}

\section{Subjek Berkemampuan Matematika Tinggi (S1)}

1. Memahami Masalah

Kemampuan dalam memahami masalah pada subjek berkemampuan matematika tinggi dapat dilihat dari Gambar 2 dan Gambar 3 berikut:

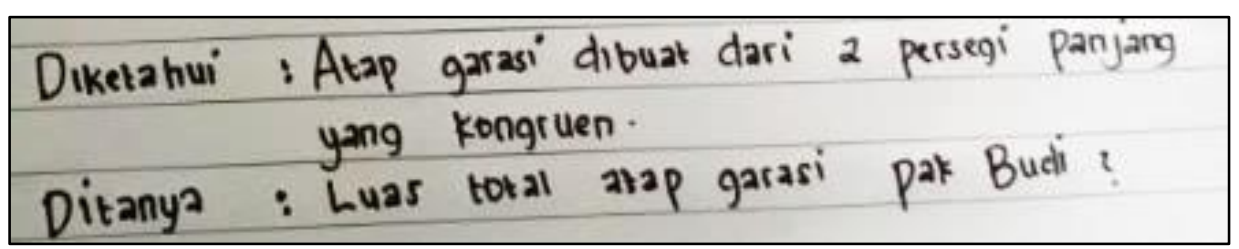

Gambar 2. Kemampuan memahami masalah subjek berkemampuan matematika tinggi

Dari Gambar 2, subjek berkemampuan matematika tinggi terlihat masih memahami masalah dalam segi permukaannya saja sebab hanya menyebutkan yang diketahui bahwa atap terbuat dari dua persegi panjang yang kongruen tanpa menuliskan atribut yang lain. Di sisi lain subjek mampu menuliskan apa yang ditanyakan dengan benar.

$l=\sqrt{2.5^{2}+1^{2}} \quad P=6 \quad L=2 \times 6 \sqrt{7.25}$

Gambar 3. Kutipan hasil pemecahan masalah subjek berkemampuan matematika tinggi

Namun meskipun demikian dari kutipan hasil pemecahan masalah subjek pada Gambar 3 dan berdasarkan wawancara yang dilakukan terhadap S1, ternyata subjek mengetahui informasi yang diberikan soal dengan tepat seperti panjangnya yang dia simbolkan dengan $p$, lebar atap yang disimbolkan dengan $l$, serta luas atap yang disimbolkan dengan $L$. Subjek juga mengetahui informasi mengenai tinggi atap dari tembok yang panjangnya 1 meter dan jarak ujung atap ke tembok yang panjangnya 2,5 meter meskipun tidak menuliskan secara jelas tapi terlihat subjek memahami dari caranya mencari informasi yang belum diketahui (lebar atap) dengan menggunakan informasi yang ada dan teorema Pythagoras. Hal ini sejalan dengan pendapat Croft dkk (2018) bahwa siswa cenderung malas menuliskan informasi-informasi yang ada pada masalah, siswa cenderung langsung mengerjakan soal yang diberikan. Hasil pemecahan masalah subjek yang ditunjukkan pada Gambar 3 menunjukkan bahwa meskipun subjek tidak menuliskan simbol panjang, lebar, dan luas pada bagian diketahui dan ditanya namun berdasaran hasil pemecahan masalah dan wawancara subjek dapat mengetahui simbol panjang, lebar dan luas dengan benar. Hal ini sama dengan pernyataan Veldhuis (2019), 
bahwa siswa berkemampuan tinggi dapat memahami simbol-simbol matematika dengan baik.

2. Merencanakan Strategi

Kemampuan merencanakan strategi pada subjek berkemampuan matematika tinggi dapat dilihat dari Gambar 4 dan Gambar 5 berikut:

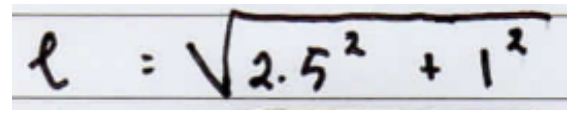

Gambar 4. Kemampuan merencanakan strategi subjek berkemampuan matematika tinggi

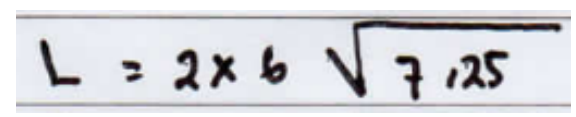

Gambar 5. Kemampuan merencanakan strategi subjek berkemampuan matematika tinggi

Dari Gambar 4 diketahui bahwa subjek berkemampuan matematika tinggi dapat merencanakan strategi untuk mencari informasi yang tidak diketahui terlebih dahulu untuk mencari permasalahan utama, informasi yang dimaksud adalah tinggi atap dari tembok dan jarak ujung atap ke tembok dengan teorema Pythagoras untuk mencari lebar atapnya (Novita \& Zulkardi, 2012). Dari Gambar 5 diketahui bahwa subjek merencanakan strategi untuk mencari permasalahan utama yakni luas total atap garasi pak Budi dengan menggunakan rumus luas persegi panjang dan dikali dengan 2 karena terbentuk dari 2 persegi panjang yang kongruen (Edo, Hartono, \& Ilma, 2013).

3. Melaksanakan Strategi

Kemampuan melaksanakan strategi subjek berkemampuan matematika tinggi dapat dilihat dari Gambar 6 dan Gambar 7 berikut:

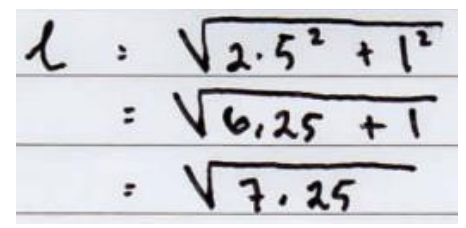

Gambar 6. Kemampuan melaksanakan strategi subjek berkemampuan matematika tinggi

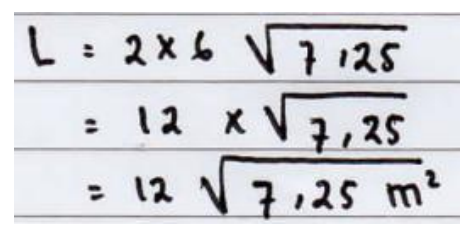

Gambar 7. Kemampuan melaksanakan strategi subjek berkemampuan matematika tinggi 
Subjek berkemampuan matematika tinggi dapat melaksanakan strategi dengan benar, yaitu strategi menemukan informasi yang belum diketahui yakni lebar atap seperti pada Gambar 6 meskipun di akhir tidak menuliskan satuan panjang, dan melaksanakan rencana untuk mencari luas total atap seperti pada Gambar 7 (Seidouvy, 2019).

4. Mengoreksi Kembali

Kemampuan siswa berkemampuan matematika tinggi dalam tahap mengoreksi kembali, dapat dilihat dalam kutipan wawancara berikut:

Guru : Setelah mendapatkan jawabannya, lalu apa yang kamu lakukan?

Siswa : Saya mengkoreksi pekerjaan saya $\mathrm{Bu}$.

Guru : Bagaimana kamu mengoreksinya?

Siswa : Dengan menghitung kembali bagian perhitungannya Bu.

Guru : Sudah? Adakah hal lain yang kamu lakukan?

Siswa : Tidak Bu, saya insya Allah yakin, cuma saya takut salah perhitungannya, soalnya hasilnya tidak bulat $\mathrm{Bu}$.

Berdasarkan kutipan wawancara tersebut, subjek berkemampuan matematika tinggi melakukan pengoreksian kembali pada bagian perhitungannya saja, dan tidak melakukan pengoreksian pada bagian rumus dan konsep dengan alasan subjek sudah yakin dengan rumus dan konsep yang digunakan serta hanya ragu pada perhitungan yang dilakukan karena hasilnya bukan merupakan bilangan bulat. Hal ini sesuai dengan penelitian yang dilakukan oleh Veldhuis (2019) yang menyebutkan bahwa subjek pada penelitiannya juga fokus dalam perhitungan ketika diharapkan untuk melakukan looking back.

\section{Subjek Berkemampuan Matematika Sedang (S2)}

1. Memahami Masalah

Kemampuan dalam memahami masalah pada subjek berkemampuan matematika sedang dapat dilihat dari Gambar 8 dan Gambar 9 berikut:

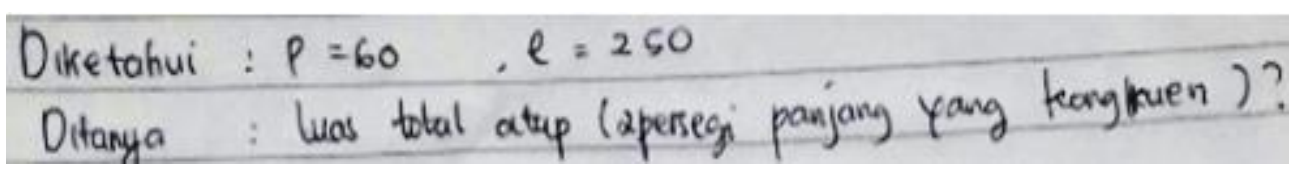

Gambar 8. Kemampuan memahami masalah subjek berkemampuan matematika sedang

Berdasarkan Gambar 8, subjek menuliskan apa yang diketahui yakni $p=60$ dan $l=250$, serta menuliskan apa yang ditanyakan yaitu luas total atap atau 2 persegi panjang yang kongruen. Jika hanya melihat Gambar 8, dapat diketahui subjek berkemampuan sedang dapat menuliskan apa yang diketahui dan ditanya seperti panjang, lebar, dan luas menggunakan simbol panjang dan lebar dengan benar, namun tidak 
menuliskan simbol luasnya, dan terlihat ketika menuliskan panjangnya adalah 60 dan lebarnya 250 subjek tidak menuliskan satuan panjangnya, hal ini sejalan dengan penelitian Kamaliyah dkk, (2013) sebagian besar siswa terpaku pada angka kuantitatif tanpa menghiraukan satuan yang menyertainya. Dilain sisi, subjek juga menganggap lebarnya adalah 250 yang mengartikan bahwa subjek masih belum memahami masalah dengan baik, sebab tidak sadar bahwa terdapat informasi lain yang belum diketahui dan salah satunya adalah lebarnya, sehingga terjadi kesalahan memahami masalahnya yang berdampak kesalahan penulisan informasi (Sari \& Rosjanuardi, 2018).

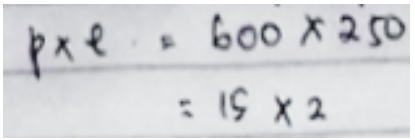

Gambar 9. Kemampuan memahami masalah subjek berkemampuan matematika sedang

Dari Gambar 8, sekilas terlihat subjek salah dalam menuliskan panjang atap yakni 60 padahal seharusnya adalah 6 meter, ternyata pada Gambar 9 dapat menujukkan bahwa subjek hanya kurang menuliskan koma pada bilangan 600 yang seharusnya 6,00 dan 250 yang seharusnya 2,50. Terlihat saat mengalikannya menghasilkan 15, dari hal ini dapat disimpulakan subjek hanya kurang teliti dan terdapat kesalahan tulis saja. Menurut Galen \& Eerde (2013) kesalahan seperti ini cukup sering ditemukan kepada siswa, karena siswa cenderung ingin segera menyelesaikan masalah yang diberikan meskipun terjadi kesalahan dalam proses pekerjaanya.

2. Merencanakan Strategi

Kemampuan dalam merencanakan strategi pada subjek berkemampuan matematika sedang dapat dilihat dari Gambar 10 berikut:

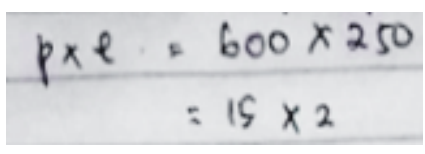

Gambar 10. Kemampuan merencanakan strategi subjek berkemampuan matematika sedang

Dari Gambar 10 didapat strategi bahwa untuk mencari luas adalah dengan mengalikan panjang atap dan lebarnya, dan karena yang ditanyakan adalah luas dari 2 persegi panjang yang kongruen maka dikalikan 2 pada baris kedua.

Subjek berkemampuan matematika sedang masih salah dalam memilih dan merencanakan strategi, hal ini bisa disebabkan karena kesalahan dalam memahami masalah pada indikator sebelumnya sehingga tidak mampu mengaitkan informasi yang ada untuk mencari informasi yang belum diketahui, dalam hal ini adalah menggunakan 
tinggi atap dari tembok dan jarak ujung atap ke tembok dengan teorema Pythagoras untuk mencari lebar atapnya, hal ini sesuai dengan hasil penelitian Maulyda, Hidayanto, \& Rahardjo (2019) bahwa siswa cenderung kesulitan dalam mengkonversi data dari wilayah konkrit pada soal ke dalam bentuk abstrak yakni hasil pekerjaanya. Hal ini berdampak pada rencana berikutnya seperti pada Gambar 10 untuk mencari luas totalnya dengan langsung mensubtitusikan nilai lebar dengan 2,50.

3. Melaksanakan Strategi

Kemampuan melaksanakan strategi dari subjek berkemampuan matematika sedang dapat dilihat dari Gambar 11 berikut:

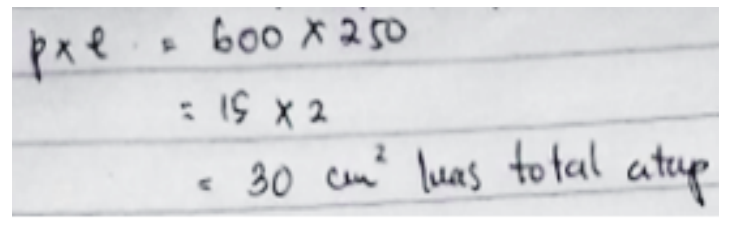

Gambar 11. Kemampuan melaksanakan strategi subjek berkemampuan matematika sedang

Dikarenakan langkah-langkah sebelumnya seperti kesalahan memahami masalah, yaitu tidak mampu untuk menghubungkan informasi untuk mencari lebar atap, mengakibatkan rencana yang dibuat kurang sesuai dengan permasalahan dan mengakibatkan strategi yang dilaksanakan kurang sesuai.. Terlihat di Gambar 11 bahwa subjek melakukan kesalahan dengan langsung mensubtitusikan lebar atap dengan 2,50. Hal ini sesuai dengan hasil penelitian Calor, dkk (2019) bahwa siswa sering melakukan kesalahan ketika proses subtitusi nilai dari masalah yang diberikan. Selanjutnya subjek berkemampuan matematika sedang terlihat pada baris pertama hanya mengalikan panjang dengan lebar saja namun pada baris kedua dikalikan dengan 2 sehingga yang terjadi adalah kesalahan struktur tulisannya, seharusnya dari atas langsung dikalikan 2 sebab ada 2 persegi panjang yang identik. Menurut Croft, dkk., (2018) kesalahan dalam konsistensi pengerjaan ini merupakan tanda bahwa konstruksi kemampaun pemecahan masalah siswa masih kurang terstruktur.

4. Mengoreksi Kembali

Untuk mengetahui kemampuan looking back yang dilakukan siswa berkategori sedang dapat dengan melihat kutipan wawancara berikut:

Guru : Lalu setelah menemukan jawaban tersebut apa yang kamu lakukan?

Siswa : Saya lihat - lihat soalnya lagi Bu, untuk memastikan lebarnya atap itu 2,5 meter.

Guru : Setelah itu? 
Siswa : Saya kumpulkan bu, soalnya setelah melihat lebar atap itu saya sudah yakin dengan jawaban saya

Subjek berkemampuan matematika sedang berdasarkan kutipan wawancara tersebut, melakukan pengkoreksian hanya pada konsepnya saja yakni pada bagian menentukan lebar atap yang dimaksud pada soal. Menurut Surya, dkk (2013) Subjek tidak melakukan pengoreksian pada bagian perhitungan dikarenakan subjek cukup yakin dengan hasil pekerjaannya.

\section{Subjek Berkemampuan Matematika Rendah (S3)}

1. Memahami Masalah

Kemampuan dalam memahami masalah pada subjek berkemampuan matematika rendah dapat dilihat dari Gambar 12 dan Gambar 13 berikut:

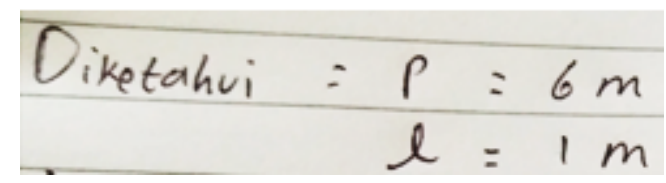

Gambar 12. Kemampuan memahami masalah subjek berkemampuan matematika rendah

Dari Gambar 12, subjek menuliskan apa yang diketahui yakni $p=6 \mathrm{~m}$ dan $l=$ $1 \mathrm{~m}$. Berdasarkan wawancara maksud dari $p$ adalah menyimbolkan panjang, dan maksud dari $l$ menyimbolkan lebar atap. Subjek berkemampuan matematika rendah masih belum bisa memahami masalah dengan benar. Terlihat dari Gambar 12 subjek menuliskan apa yang diketahui masih belum benar meskipun telah dapat menuliskan simbol panjang dan lebar dengan tepat. Hal ini terjadi karena subjek memiliki kemampuan spasial yang masih kurang baik, sehingga subjek hanya melihat "gambar sebelah kanan" atau gambar “tampak dari samping” saja. Maka didapatkan lebarnya 1 meter (Surya, dkk, 2013).

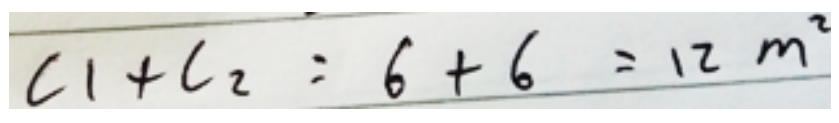

Gambar 13. Kemampuan memahami masalah subjek berkemampuan matematika rendah

Dari gambar 13, subjek menuliskan total luas dengan menambahkan $L_{1}$ dan $L_{2}=$ $6+6=12 \mathrm{~m}^{2}$. Dari hasil pemecahan masalah tersebut dapat menyiratkan apa yang dipahami oleh subjek berkemampuan matematika rendah. Berdasarkan Gambar 13, subjek mengetahui apa yang ditanyakan oleh soal dengan benar dan menggunakan simbol yang 
tepat (Sari \& Rosjanuardi, 2018), meskipun tidak dituliskan pada bagian "ditanyakan" namun pada pekerjaannya subjek mengetahui bahwa yang ditanyakan adalah luas total atap, terlihat dari Gambar 13 subjek mencari luas atap total dengan $\operatorname{simbol} \mathrm{L}_{1}+\mathrm{L}_{2}$.

2. Merencanakan Strategi

Kemampuan dalam merencanakan strategi pada subjek berkemampuan matematika rendah dapat dilihat dari Gambar 14 dan Gambar 15 berikut:

\section{$l=1 \mathrm{~m}$}

Gambar 14. Kemampuan merencanakan strategi subjek berkemampuan matematika rendah

Dari Gambar 14 terlihat bahwa subjek belum mampu untuk mengaitkan informasi yang ada untuk mencari informasi yang belum diketahui, dalam soal adalah mengaitkan tinggi atap dari tembok dan jarak ujung atap ke tembok untuk mencari lebarnya (Edo, dkk, 2013).

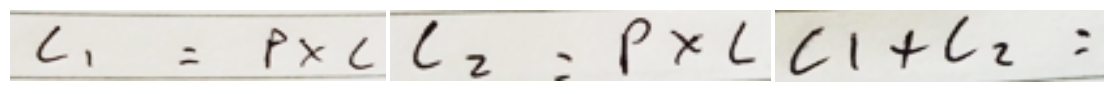

Gambar 15. Kemampuan merencanakan strategi subjek berkemampuan matematika rendah

Dari gambar 15, subjek menuliskan strateginya dengan mencari $L_{1}=p \times l$, lalu mencari lebar atap yang lain dengan $L_{2}=p \times l$, setelah itu mencari luas total yakni $L_{1}+$ $L_{2}$. Sebenarnya secara garis besar subjek merencanakan cara mencari luas total atap dengan cukup benar yakni seperti pada Gambar 15 yaitu mencari luas atapnya kemudian menjumlahkannya. Namun secara keseluruhan subjek berkategori rendah dikatakan belum mampu menyusun strategi yang tepat karena terjadi kegagalan dalam mengaitkan informasi seperti pada Gambar 14 sehingga berdampak pada rencananya (Galen \& Eerde, 2013).

3. Melaksanakan Strategi

Kemampuan malaksanakan strategi subjek berkemampuan matematika rendah dapat dilihat dari Gambar 16 berikut: 


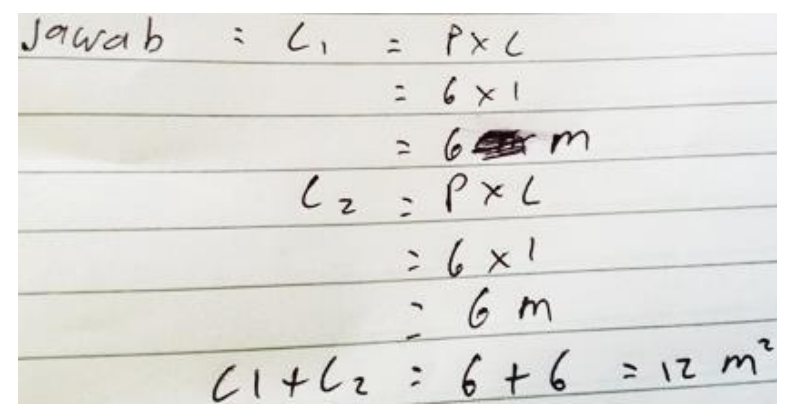

Gambar 16. Kemampuan melaksanakan strategi subjek berkemampuan matematika rendah

Subjek berkemampuan matematika rendah melaksanakan strategi seperti pada Gambar 16 yakni dengan beranggapan bahwa lebar atapnya adalah 1, sehingga mencari $L_{1}=6 \times 1=6 \mathrm{~m}$ dan $L_{2}=6 \times 1=6 \mathrm{~m}$, lalu selanjutnya menjumlahkan dua luas atap tersebut yakni $L_{1}+L_{2}=6+6=12 \mathrm{~m}^{2}$. Meskipun yang dilaksanakan adalah strategi yang salah sebagai dampak kurangnya kemampuan memahami masalah dan menyusun strategi. Namun ada keunikan dalam pelaksanaan strategi yang salah tersebut. Bisa dilihat dari Gambar 16 subjek mencari luas persegi panjang pertama dan luas persegi panjang kedua. Kemudian subjek menuliskan luas persegi panjang pertama dan kedua adalah 6 meter. Padahal satuan luas yang benar untuk soal ini adalah meter persegi $\left(\mathrm{m}^{2}\right)$. Uniknya pada bagian akhir yakni menghitung luas total subjek menuliskan satuan luasnya yakni meter persegi (Edo, dkk., 2013).

4. Mengoreksi Kembali

Untuk mengukur sejauhmana looking back yang dilakukan siswa berkategori matematika rendah dapat dengan melihat kutipan wawancara berikut:

Guru : Terus apa yang kamu lakukan setelah menemukan jawabannya?

Siswa : Ya sudah bu, selesai saya kumpulkan.

Subjek berkemampuan matematika rendah berdasarkan hasil wawancara, tidak melakukan pengoreksian kembali baik dalam perhitungan, rumus maupun konsepnya dengan alasan subjek cukup yakin dengan perhitungan dan rumusnya, serta sudah menentukan lebar yang digunakan pada awal pengerjaan dengan waktu yang cukup lama. Hal ini sejalan dengan pendapat Murni, dkk (2011), bahwa anak yang berada pada ketegori kemampuan matematika rendah sering melewatkan tahapan pengecekan sehingga hasi akhir yang didapat cenderung tidak tepat. 


\section{Simpulan}

Bertolak dari temuan penelitian dan pembahasan tersebut, dapat diambil beberapa kesimpulan yakni kesalahan pada satu langkah pemecahan masalah saja dapat berdampak besar pada langkah pemecahan masalah berikutnya. Pada penelitian ini, subjek sedang dan rendah mengalami masalah pada tahap memahami masalah, sehingga membuat mereka merancang dan melaksanakan strategi yang salah.

\section{Referensi}

Ambarwati, Setiawan, T. B., \& Yudianto, E. (2018). Analisis kemampuan visual spasial siswa dalam menyelesaikan soal matematika berstandar PISA konten shape and space ditinjau dari level berpikir geometri Van Hiele. Kadikma, 9(3), 51-60.

Calor, S. M., Dekker, R., Drie, J. P. V., \& Zijlstra, B. J. H. (2019). Let us discuss math: Effects of shift-problem lessons on mathematical discussions and level raising in early algebra. Mathematics Education Research Journal, 34(2), 8-25. https://doi.org/10.1007/s13394-019-00278-x.

Croft, T., Kouvela, E., \& Martinez, P. M. (2018). This is what you need to be learning: an analysis of messages received by first-year mathematics students during their transition to university. Math Ed Res J, 30(1), 165-183. https://doi.org/10.1007/s13394-017-02262.

Creswell, J. W. (2012). Educational research: planning, conducting, and evaluating quantitative and qualitative research 4th edition. Boston: Pearson.

Galen, F. Van, \& Eerde, D. V. (2013). Solving problems with the percentage bar. Journal on Mathematics Education, 4(1), 1-8. https://doi.org/10.22342/jme.4.1.558.1-8.

Edo, S. I., Hartono, Y., \& Putri, R. I. I. (2013). Investigating secondary school students' difficulties in modeling problems PISA-Model level 5 and 6. Journal on Mathematics Education, 4(1), 41-58. https://doi.org/10.22342/jme.4.1.561.41-58.

Haji, S., Yumiati, \& Zamzaili. (2018). Analisis kesulitan siswa dalam menyelesaikan soalsoal PISA (Programme for International Student Assessment) di SMP Kota Bengkulu. Jurnal Pendidikan Matematika Raflesia, 3(2), 177-179.

Kamaliyah, Zulkardi, \& Darmawijoyo. (2013). Developing the sixth level of PISA-Like mathematics problems for secondary school students. Journal on Mathematics Education, 4(1), 9-28. https://doi.org/10.22342/jme.4.1.559.9-28.

Lestari, L. \& Sofyan, D. (2014). Perbandingan kemampuan pemecahan masalah siswa dalam matematika antara yang mendapat Pembelajaran Matematika Realistik (PMR) dengan pembelajaran konvensional. Jurnal Pendidikan Matematika, 3(2), 95-107. https://doi.org/10.20527/edumat.v2i1.607.

Maulyda, M. A., Hidayanto, E., \& Rahardjo, S. (2019). Representation of trigonometry graph function collage students using GeoGebra. International Journal of Trends in Mathematics Education Research, 2(4), 1-7.

Murdiyani, N. M., Putri, R. I. I., Eerde, D. V., \& Van, F. (2013). Developing a Model to Support Students in Solving Subtraction. Journal on Mathematics Education, 4(1), 95112. https://doi.org/10.22342/jme.4.1.567.95-112.

Murni, A., Sabandar, J., Kusumah, Y. S., \& Kartasamita, B. G. (2011). The enhancement of junior high school students' skill-based metacognitive learning. Journal Mathematics Education, 5(2), 194-203. 
Nalurita, B. R., Nurcahyono, A., Walid, Wardono. (2019). Optimalisasi pemecahan masalah matematis pada pembelajaran Problem Based Learning (PBL) berbantuan E-Comic Math. PRISMA, Prosiding Seminar Nasional Matematika 2, 395-402.

Novita, R., Prahmana, R. C. I., Fajri, N., Putra, M. (2018). Penyebab kesulitan belajar geometri dimensi tiga. Jurnal Riset Pendidikan Matematika, 5(1), 18-29. https://doi.org/10.21831/jrpm.v5i1.16836.

Novita, R., Zulkardi, Hartono, Y. (2012). Exploring primary student's problem-solving ability by doing tasks like PISA's question. Journal on Mathematics Education, 3(2), 133-150. https://doi.org/10.22342/jme.3.2.571.133-150.

OECD. (2019). PISA 2018 Results (volume i): what students know and can do. Paris: OECD Publishing.

Oktaviana, D. V., Syarifmen, \& Putra, R. W. (2018). Analisis kemampuan pemecahan masalah matematis siswa kelas IX MTs dalam menyelesaikan soal model PISA pada konten perubahan dan hubungan. JES-MAT, 4(1), 47-56. https://doi.org/10.25134/jesmat.v4i1.909.

Polya, G. (2004). How to solve it. New Jersey: Princeton University Press.

Sari, D. P., \& Rosjanuardi, R. (2018). Errors of students learning with React strategy in solving the problems of mathematical. Journal on Mathematics Education, 9(1), 121128. https://doi.org/10.22342/jme.9.1.4378.121-128.

Seidouvy, A. (2019). An inferentialist account of students' collaboration in mathematics education. Mathematics Education Research Journal, 8(2), 67-82. https://doi.org/10.1007/s13394-019-00267-0.

Sholihah, S. Z. \& Afriansyah, E. A. (2017). Analisis kesulitan siswa dalam proses pemecahan masalah geometri berdasarkan tahapan berpikir Van Hiele. Mosharafa, 6(2), 287-298. https://doi.org/10.31980/mosharafa.v6i2.317.

Surya, E., Sabandar, J., Kusumah, Y. S., \& Darhim. (2013). Improving of junior high school visual thinking representation ability in mathematical problem solving by ICT. Journal on Mathematics Education, 4(1), 113-126. https://doi.org/10.22342/jme.4.1.568.113126.

The National Council of Teachers of Mathematics [NCTM]. (2000). Principles and standards for school mathematics. Reston, VA: The National Council of Teachers of Mathematics, Inc.

Veldhuis, M. (2019). Supporting primary school teachers' classroom assessment in mathematics education: effects on student achievement. Mathematics Education Research Journal, 13(4), 102-114. https://doi.org/10.1007/s13394-019-00270-5. 